\title{
PERANGKAT PEMBELAJARAN IPA BERPOLA PBMP DIPADU SCIENTIFIC APPROACH TERINTEGRASI NILAI ISLAMI UNTUK BERPIKIR KRITIS DAN METAKOGNISI SISWA SEKOLAH/MADRASAH MULTIETNIS
}

\author{
Ade Haerullah, Said Hasan, Muhktar Yusuf \\ FKIP Universitas Khairun \\ biohaerllah@gmail.com
}

\begin{abstract}
This study aims to determine the potential of learning models with the Pattern of Empowerment Thinking Through Questions (PBMP) combined with integrated scientific approach integrated Islamic values in empowering critical thinking and metacognition of elementary school students or madrasah ibtidaiyah. Furthermore, this study aimed to determine differences in critical thinking and metacognition of students with different ethnicities related to the learning model applied. This research is classified as a quasi experiment, conducted in the 2018/2019 school year in class $V$ at two Ibtidaiyah Madrasahs classified as schools or multiethnic Madrasas in Ternate City. The measured variables in this study were students' critical thinking skills and metacognition. To test the hypotheses, Anakova in the SPSS 16.0 program was used. If the probability value is significant, then further tests with LSD. The results of data analysis show that PBMP learning combined with integrated scientific approach integrated Islamic values has an effect on students 'critical thinking and metacognition and or it can be said that PBMP patterned learning combined with an integrated scientific approach integrated Islamic values is more empowering students' critical thinking and metacognition than conventional models. There are differences in students' critical thinking between ethnic groups in the class applied to the model, these differences can be concluded that students in each ethnic group have different learning styles.
\end{abstract}

Keywords: multiethnic, PBMP, scientific approach, Islamic values, Metacognition, critical thinking.

\section{PENDAHULUAN}

Pelaksanaan pembelajaran IPA oleh guru di Madrasah Ibtidaiyah (MI) atau sekolah yang memiliki etnis yang beragam merupakan suatu tantangan yang perlu diperhatikan. Kemajemukan masyarakat menjadi potensi dan kekayaan jatidiri bangsa bagi pembangunan daerah maupun nasional, sehingga patut disebut kemajemukan masyarakat merupakan suatu kelebihan dan atau kekuatan dalam bermasyarakat, tetapi dengan kemajemukan juga diduga dapat menyimpan potensi 
konflik, selain itu kemajemukan juga dapat berpengaruh terhadap mutu pembelajaran di kelas.

Hasil observasi oleh Hasan dkk,(2015) menunjukkan bahwa pembelajaran yang terjadi di Madrasah khususnya pada matapelajaran eksakta belum berorentasi pada pengembangan kemampuan berpikir tinggi siswa sehingga berdampak pada rendahnya penguasaan siswa terhadap materi yang diajarkan. Lebih lanjut Hasan dkk, (2015) juga melaporkan bahwa pendekatan dan model pembelajaran yang digunakan oleh guru di madrasah pada umumnya masih perpusat pada guru, sehingga siswa kurang dilibatkan dalam proses belajar mengajar. Sebagian besar perangkat pembelajaran (RPP) mata pelajaran eksakta belum tersusun dengan baik. Fakta empirik menunjukkan bahwa sebagaian besar guru matapelajaran eksakta di beberapa madrasah ibtidaiyah dan madrasah tsanawiyah belum menyusun perangkat pembelajaran dengan baik bahkan belum mengintegrasikan nilai-niai islami.

Terkait Pembelajaran di dalam kelas multietnis, Menurut Menurut Haerullah (2012) lebih sukar dilaksanakan daripada kelas monoetnis. Hal tersebut dikarenakan setiap siswa yang berasal dari etnis tertentu membawa pandangan dan perilaku ciri khas budaya masing-masing dalam menerima bahan pembelajaran dan menerima teman atau guru. Penerimaan teman dari etnis berbeda membutuhkan stimulus yang baik, dengan demikian diharapkan kepada guru agar berperan positif. Lebih lanjut dijelaskan oleh Haerullah (2012) bahwa untuk mengatasi kelemahan ini hendaklah ditemukan suatu strategi pengajaran yang lebih baik yakni starategi yang relevan dengan karakteristik daerah multietnis. Sasaran utama strategi ini adalah siswa.

Menurut Kusmarni (2011) bahwa proses pembelajaran yang harus dikembangkan di sekolah multietnis yaitu proses pembelajaran yang menempatkan peserta didik pada kenyataan sosial di sekitarnya. Salah satu strategi dan teknik mengajar yang sesuai untuk diterapkan pada kelas multietnis adalah model pembelajaran kooperatif. Pernyataan tersebut didukung oleh hasil penlitiannya Haerullah (2012) yang mengemukakan bahwa pembelajaran berpola PBMP dipadu TPS sangat tepat diterapkan di sekolah multietnis dan lebih berpotensi mengembangkan berpikir kritis, keterampilan metakognisi, dan sikap sosial siswa. Selanjutnya oleh Darmadi (2011) berpendapat bahwa gaya mengajar guru yang paling tepat pada sekolah multietnis adalah metode belajar kooperatif atau cooperative learning.

Berpikir kritis siswa merupakan salah satu keterampilan berpikir tingkat tinggi. Menurut Corebima (2009), pemberdayaan penalaran hampir tidak 
pernah/sangat jarang diperhatikan dan dilaksanakan di setiap gerak pembelajaran di Indonesia. Menurut Haerullah (2013) bahwa fenomena terkait belum diberdayakannya keterampilan berpikir tingkat tinggi, khususnya keterampilan berpikir kritis, juga terjadi di setiap jenjang pendidikan di Maluku Utara, khususnya di SD/MI Kota Ternate.

Mengingat pentingnya keterampilan berpikir pada proses pembelajaran, maka pemberdayaannya harus segera dilakukan. Salah satu strategi pembelajaran yang mampu memberdayakan keterampilan berpikir tingkat tinggi siswa yaitu pembelajaran kooperatif (Corebima, 2010).

Menurut Corebima (2008) bahwa Pola Pemberdayaan Berpikir Melalui Pertanyaan (PBMP) mendorong siswa untuk mengatur proses berpikir mereka melalui pertanyaan-pertanyaan yang tersusun secara sistematis dan terarah. Pembelajaran berpola PBMP mampu memberdayakan siswa untuk menjawab pertanyaan-pertanyaan yang tersusun secara sistematis. Pembelajaran berpola PBMP tidak berlangsung secara informatif. Pola pembelajaran tersebut mampu memicu anak untuk berpikir sehingga apabila pola PBMP diterapkan secara terusmenerus diyakini mampu meningkatkan kemampuan berpikir dan anak mampu mengatur proses berpikir mereka. Pengaturan proses berpikir inilah kemudian dapat disebut dengan ketarampilan berpikir kritis siswa.

Salah satu kelebihan dari pembelajaran berpola PBMP ini adalah dapat diterapkan dengan menggunakan banyak metode, model, dan pendekatan. Salah satu pendekatan yang diduga berpotensi untuk dipadukan dengan pola pembelajaran PBMP adalah pendekatan saintifik (scientific approach) dan terintegrasi nilai-nilai islami. Perpaduan scientific approach dengan PBMP dan teringrasi nilai Islami dapat dilakukan karena keduanya memiliki karateristik pembelajaran yang sama yakni keduanya sama-sama memberdayakan siswa untuk berikir kritis dan kreatif.

Alasan lainnya, karena pembelajaran saintifik merupakan pembelajaran yang mengadopsi langkah-langkah saintis dalam membangun pengetahuan melalui metode ilmiah, maka model pembelajaran yang diperlukan adalah model yang memungkinkan terbudayakannya kecakapan berpikir sains, berkembangkannya "sense of inquiry" dan kemampuan berpikir kreatif siswa.

Model PBMP maupun scientific approach memiliki beberapa prinsip pembelajaran yang sama yakni; Pembelajaran berpusat pada siswa, pembelajaran membentuk students self concept, pembelajaran terhindar dari verbalisme, pembelajaran mendorong terjadinya peningkatan kemampuan berpikir siswa, 
dan memberikan kesempatan kepada siswa untuk melatih kemampuan dalam komunikasi

Berdasarkan hasil survei terhadap guru SD/MI di Kota Ternate menunjukkan bahwa: (1) $75 \%$ guru pernah menerapkan model pembelajaran kooperatif, namun belum pernah menerapkan model pembelajaran PBMP; (2) guru mendesain perangkat pembelajaran tidak berdasarkan karakteristik suatu model pembelajaran tertentu, dan tidak memperhatikan karakteristik siswa yang beragam etnisnya; (3) guru belum sepenuhnya menerapkan pendekatan scientific approach, apalagi mengintegrasikan ke dalam model-model pembelajaran lain, (4) guru belum memberdayakan siswa untuk berpikir kritis dan metakognisi selama pembelajaran. (5) terdapat $97 \%$ guru di madarsah belum mengintegrasikan nilainilai islami dalam perangkat pembelajaran maupun dalam proses pembejaran, (6) terdapat $100 \%$ guru di madarasah belum memperhatikan keberagaman etnis dalam menyusun RPP.

Hasil survei tersebut, dapat dimaknai bahwa selama ini guru-guru masih mengabaikan pemberdayaan berpikir kritis dan metakognisi siswa multietnis. Berdasarkan fakta yang ada, maka proses pembelajaran, dalam hal ini proses pembelajaran IPA-Biologi di SD/MI Kota Ternate perlu segera menerapkan model pembelajaran kooperatif yang diharapkan mampu memberdayakan keterampilan berpikir kritis dan metakognisi siswa multietnis.

Permasalahan terkait rendahnya hasil belajar siswa SD di Kota Ternate dengan karakter siswa yang multietnis diharapkan dapat tersolusikan dengan penerapan model pembelajaran kooperatif berpola PBMP dipadu scientific approac terintegrasi nilai Islami. Terkait dengan hal tersebut, pada penelitian ini ditujukan untuk mengetahui perbedaan potensi antara model pembelajaran PBMP dipadu scientific approac terintegrasi nilai Islami dengan model pembelajaran konvensional dalam memberdayakan berpikir kritis siswa. Lebih lanjut penelitian ini ditujukan untuk mengetahui perbedaan keterampilan berpikir kritis siswa dengan etnis yang berbeda terkait dengan strategi pembelajaran yang diterapkan.

Menurut Haerullah (2018), guru IPA harus mampu memberikan bekal konsep dasar keilmuan IPA secara mendalam, sehingga peserta didik dapat memanfaatkannya sebagai sarana berpikir kreatif dan inovatif dalam belajar. Kemajuan ilmu pengetahuan dan teknologi harus dimanfaatkan secara baik oleh guru, sehingga guru secara cepat dan tepat melakukan inovasi dan kreatiftas dalam mendukung pembelajaranya. Sebagai fasilitator, motivator, dan inspirator guru senantiasa diharapkan dapat mendesain pembelajaran sedemikian rupa sehingga 
mampu memotivasi dan menginspirasi peserta didiknya untuk kreatif dan inovatif dalam belajar.

Kajian terkait penerapan pembelajaran berpola PBMP dipadu scientific approac terintegrasi nilai Islami dalam pengajaran multietnis, khususnya di SD/MI Kota Ternate terhadap berpikir kritis dan metakognisi siswa telah diungkap oleh Haerullah $\left(2012^{\mathrm{a}}\right)$, namun belum tersentuh pada sekolah di kalangan kementerian agama terutama pada Madrasah Ibtidaiyah (MI) maka secara keseluruhan, penelitian ini ditujukan untuk mengungkap potensi pembelajaran berpola PBMP terintegrasi scientific approach terhadap berpikir kritis dan metakognisi siswa kelas V MI Kota Ternate.

\section{METODE PENELITIAN}

Penelitian ini adalah tipe penelitian Quasi experiment dengan rancangan pretest-postest nonequivalent control group design pola (Ary dkk., 1982; Sukardi, 2008; Sugiyono, 2009). Quasi experiment dilaksanakan di kelas V Madrasah Ibtidaiyah (MI) dengan rancangan faktorial $2 \times 3$.

Variabel bebas dalam penelitian ini adalah model pembelajaran dan macammacam etnis siswa. Strategi pembelajaran terdiri dari dua level, yaitu model pembelajaran PBMP dipadu scientific approac terintegrasi nilai Islami dan model konvensional. Penerapan model pembelajaran tersebut pada empat sekolah yang telah ditetapan yaitu: model pembelajaran berpola PBMP terintegrasi saintifik diterapkan di Madrasah Ibtidaiyah Negeri (MIN) 1 kota Ternate, model pembelajaran berpola PBMP diterapkan di Madrasah Ibtidaiyah Negeri (MIN) 1 kota Ternate, pembelajaran saintifik diterapkan di Madrasah Ibtidaiyah Alma'arif 1 kota Ternate dan model pembelajaran konvensional diterapkan di Almaarif 2 kota Terrnate. Macam etnis terdiri dari tiga etnis lokal, yaitu etnis Ternate, Tidore, dan Makian. Variabel yang diukur dalam penelitian ini adalah keterampilan berpikir kritis dan metakognisi. Pengukuran berpikir kritis dan metakognisi terintegrasi dalam tes essay. Berpikir kritis diukur dengan menggunakan rubrik keterampilan berpikir kritis yang mengacu kepada Hart (1994), sedangkan rubrik metakognisi digunakan untuk menentukan skor keterampilan metakognisi yang terintegrasi dengan tes essay pemahaman konsep (Corebima, 2009).

Analisis data penelitian untuk pengujian hipotesis dilakukan dengan Anakova dalam program SPSS 16.0. Apabila nilai probability (p) lebih kecil dari nilai $\alpha=0.05$, maka dilakukan uji lanjut dengan menggunakan uji LSD. Atas dasar analisis data tersebut, selanjutnya diketahui strategi pembelajaran mana yang 
paling berpotensi memberdayakan keterampilan berpikir kritis dan metakognisi pada siswa multietnis.

\section{PEMBAHASAN}

\section{a. Hasil Penelitian Pengaruh PBMP dipadu scientific approac terintegrasi nilai Islami Terhadap Metakognisi Siswa Madrasah Ibtidaiyah (MI) Multietnis}

Berdasarkan hasil analisis stastik deskriptif, menunjukkan bahwa: 1) terjadi peningkatan rata-rata nilai kesadaran metakognisi siswa setelah diberi perlakuan secara berurutan dari tertinggi sampai terendah sebesar 24,6-4,2, 2) terjadi peningkatan rata-rata nilai metakognisis pada kelompok etnis sbebelum setelah diberi perlakuan secara berurutan dari tertinggi sampai terendah 17,0-15,7dan 3) terjadi peningkatan rata-rata metakognisi pada kelompok interaksi startegi dan etnis setelah diberi perlakuan sebesar secara berurutan dari tertinggi sampai terendah 27,2-3,3.

Hasil analisis data metakognisi berdasarkan pretest dan posttest menunjukkan bahwa terjadi peningkatan metakognisi siswa pada kelompok model sebesar 6,9\%-45,0\%, pada kelompok etnis sebesar 26,6\%,-29,2\%,. Berdasarkan hasil Anakova tersebut dapat dilanjutkan dengan uji lanjut LSD menunjukkan bahwa rata-rata metakognisi siswa pada kelompok model pembelajaran PBMP dipadu scientific approac terintegrasi nilai Islami berbeda nyata dengan pembelajaran konvensional. Terkait dengan etnis, hasil analisis kovarians menunjukkan bahwa kelompok etnis tidak berpengaruh terhadap metakognisi siswa. Artinya, dapat dijelaskan bahwa tiap etnis memiliki tingkat penyesuaian belajar yang berbeda atas model pembelajaran berpola PBMP dipadu scientific approac terintegrasi nilai Islami yang diterapkan oleh guru. Atas dasar hasil tersebut terlihat bahwa kelompok kombinasi model pembelajaran PBMP dipadu scientific approac terintegrasi nilai Islami dengan etnis lebih tinggi dibanding kelompok kombinasi lainnya.

\section{Pengaruh PBMP Dipadu Scientific Approac Terintegrasi Nilai Islami Terhadap Berpikir Kritis Siswa Madrasah Ibtidaiayah (MI) Multietnis}

Berdasarkan hasil analisis stastik deskriptif, menunjukkan bahwa: 1) terjadi peningkatan rata-rata nilai berpikir kritis pada kelompok strategi setelah diberi perlakuan secara berurutan dari terendah sampai tertinggi adalah secara berurutan 
dari tertinggi sampai terendah sebesar $39,9-22,5,2)$ terjadi peningkatan rata-rata nilai berpikir kritis pada kelompok etnis setelah diberi perlakuan secara berurutan dari tertinggi sampai terendah sebesar 36,2-29,0, dan 3) terjadi peningkatan ratarata keterampilan berpikir kritis pada kelompok interaksi startegi dan etnis setelah diberi perlakuan secara berurutan dari terendah sampai tertinggi secara berurutan dari tertinggi sampai terendah sebesar 42,6-14,1.

Persentase nilai berpikir kritisi siswa multietnis menunjukkan bahwa persentase perubahan nilai pada kelompok model sebesar 3,2-2,1\%, kelompok etnis sebesar 3,6\%-2,1\%, dan pada kelompok kombinasi model dan etnis, sebesar 1,1\%-3,8\%. Hal ini dapat dijelaskan bahwa; 1) ada pengaruh model terhadap keterampilan berpikir kritis, 2) tidak ada pengaruh etnis terhadap keterampilan berpikir kritis siswa, dan 3) tidak ada pengaruh interaksi model dan etnis terhadap keterampilan berpikir kritis siswa. Berdasarkan hasil Anakova, maka analisis dapat dilanjutkan dengan uji LSD untuk mengetahui perbedaan rata-rata dari setiap level kelompok model, kelompok etnis dan kelompok kombinasi model dengan etnis.

Berdasarkan hasil analisis kovarians, terlihat bahwa interaksi model dan etnis tidak berpengaruh signifikan terhadap keterampilan berpikir kritis, namun dilanjutkan dengan uji LSD untuk mengetahui perbedaan rata-rata keterampilan berpikir kritis pada masing-masing level interaksi. Hasil uji LSD tekait keterampilan berpikir kritis, menunjukkan bahwa masing-masing etnis memiliki tingkat penyesuaian belajar yang berbeda atas model pembelajaran yang diterapkan oleh guru. Atas dasar hasil uji LSD tersebut dapat disimpulkan bahwa keterampilan berpikir kritis pada kelompok kombinasi model PBMP terintegrasi saintifik dengan etnis lebih tinggi dibanding kelompok kombinasi strategi pembelajaran konvensional dengan etnis.

\section{b. Pembahasan}

Hasil analisis data yang telah diuraikan sebelumnya menunjukkan bahwa strategi pembelajaran berpola PBMP dipadu scientific approac terintegrasi nilai Islami berpengaruh signifikan terhadap metakognisi siswa. Adanya pengaruh penerapan model pembelajaran berpola PBMP dipadu scientific approac terintegrasi nilai Islami terhadap metakognisi disebabkan oleh berbagai faktor. Salah satu faktor penyebabnya adalah kelebihan dan keunggulan dari karakteristik model tersebut.

Hasil penelitian ini tidak sejalan dengan beberapa hasil penelitian yang dilakukan sebelumnya oleh (Danial, 2010; Prayitno, 2010; dan Jahidin, 2009) yang melaporkan bahwa model tidak berpengaruh signifikan terhadap metakognisi. Penyebab perbedaan hasil penelitian ini dengan hasil penlitian sebelumnya adalah 
penggunaan model pembelajaran yang berbeda, lokasi penelitian yang berbeda, dan waktu yang berbeda. Selain itu, yang menyebabkan model dapat berpengaruh terhadap metakognisi siswa pada hasil penelitian ini adalah kepolosan siswa dalam menjawab atau mengisi kuesioner atau Metakognitive Junior Inventory (MJI).

Potensi pembelajar berpola PBMP terlihat bahwa dalam proses pembelajaran, model pembelajaran ini memberikan waktu siswa untuk berpikir dan mengevaluasi jawaban mereka ketika tahap lakukan dan berdiskusi, model ini juga mendorong siswa untuk mengatur proses berpikir mereka melalui pertanyaanpertanyaan yang tersusun secara sistematis dan terarah pada LS PBMP maupun LKS. Kegiatan yang dilakukan oleh siswa dalam proses pembelajaran pada tahap "lakukan" pada sintaks PBMP dapat meningkatkan kesadaran siswa, karena tahaptahap ini akan memacuh siswa untuk berinteraksi dan bekerja sama dengan sesama temannya. Hal ini terjadi karena pada pembelajaran berpola PBMP, tidak ada proses pembelajaran yang berlangsung secara informatif.

Hasil penelitian ini sejalan dengan Corebima (2009) bahwa penerapan macam model pembelajaran dapat melatih pebelajar untuk berbicara kepada diri sendiri dan membuat pebelajar untuk selalu membantu dan meregulasi perilakunya sendiri. Corebima (2009) juga melaporkan bahwa pembelajaran berpola PBMP terbukti juga berpotensi memberdayakan metakognisi siswa.

Hasil uji LSD menunjukkan bahwa pembelajaran berpola PBMP berbeda nyata dan lebih berpotensi mengembangkan kesadaran metakognisi siswa dibanding pembelajaran konvensional. Hal ini sejalan dengan hasil penelitiannya Arsad (2010) yang melaporkan bahwa ada pengaruh strategi pembelajaran terhadap kesadaran metakognisi, keterampilan metakognisi dan hasil belajar kognitif mahasiswa. Temuan ini diperkuat oleh pernyataan Hogan (1999) yang dikutip oleh Habibah, 2008) bahwa kemampuan metakognisi siswa dipengaruhi pula oleh pembelajaran kooperatif.

Kegiatan-kegiatan yang dilakukan oleh siswa dalam proses pembelajaran dengan mengikuti sintaks pembelajar berpola PBMP menyebabkan siswa dapat belajar dan memperbaiki hasil belajarnya dengan cara memperbaiki kesalahannya melalui pemantauan dan pengevaluasian terhadap hasil pikirannya (Slavin, 2005). Djiwandono (2006) menjelaskan bahwa ketika anak berkembang, maka anak menjadi lebih cermat dalam pengertian bagaimana mengontrol dan memonitor belajar anak itu sendiri serta bagaimana menggunakan bahasa untuk berkomunikasi. Kemampuan metakognitif perlu diberdayakan melalui strategistrategi pembelajaran di sekolah untuk memonitor hasil belajar siswa sendiri, agar dapat berkembang. Arends (1997) yang dikutip oleh Miranda (2009) bahwa 
pengetahuan metakognitif merupakan pengetahuan seseorang tentang pembelajaran diri sendiri atau kemampuan untuk menggunakan strategi-strategi belajar tertentu dengan benar. Selanjutnya Rivers (2001), Schraw dan Dennison (1994) menjelaskan bahwa siswa yang terampil melakukan penilaian terhadap diri sendiri adalah siswa yang sadar akan kemampuannya.

Berdasarkan hasil analisis data, dapat disimpulkan bahwa etnis tidak berpengaruh signifikan terhadap kesadaran metakognisi siswa. Hal ini dapat dimaknai bahwa metakognisi siswa yang tidak berbeda tersebut, disebabkan karena siswa etnis Ternate, Makian, dan Tidore memiliki kemampuan yang sama dalam hal mengurangi perbedaan di antara mereka, saling terbuka antara etnis yang satu dengan etnis lainnya, meningkatkan kesatuan tindakan dan sikap untuk mencapai tujuan bersama. Sebagai contoh misalnya, mereka menggunakan bahasa Indonesi baku dan bahasa Melayu Ternate dalam membangun hubungan antaretnis. Hasil penelitian ini sejalan dengan Liliweri (2009) yang dikutip oleh Haerullah (2012) bahwa kemampuan membangun hubungan antaretnis melalui proses asimilasi dan akulturasi karena adanya faktor-faktor pendorong seperti; toleransi, kesempatan yang seimbang dalam bidang sosial dan ekonomi, sikap menghargai orang lain, sikap terbuka dari etnis yang satu dengan etnis lainnya, dan upaya bersama untuk menyamakan unsur budaya dalam suatu tempat.

Metakognisi siswa etnis Makian dan Tidore (etnis pendatang), juga terbukti tidak berbeda dengan kesadaran metakognisi siswa etnis Ternate (asli kota Ternate). Hal ini disebabkan karena kedua etnis tersebut memiliki kemampuan dalam berinteraksi untuk membangun hubungan antaretnis. Menurut pendapat Haerullah $\left(2012^{\mathrm{a}}\right)$ dalam hasil penelitiannya bahwa sebagai etnis pendatang, etnis Makian dan Tidore harus memiliki kemampuan dalam berinteraksi sosial yang baik melalui proses akulturasi dan asimilasi. Melalui proses akulturasi dan asimilasi, masyarakat etnis Makian dan Tidore mampu mentrasformasikan identitas etnisnya dan mengadaptasikan budayanya dengan budaya etnis Ternate. Selanjutnya oleh Rahmat (2009) menegaskan bahwa hubungan antaretnis dapat seimbang atau sama, apabila terjadi hubungan sosial antaretnis melalui adaptasi budaya. Artinya setiap kelompok etnis dapat mengadaptasikan kebudayaannya ke dalam kebudayaan etnis lain. Perubahan etnis merupakan akibat dari modifikasi perilaku kelompok untuk mempersempit batasan-batasan etnis. Agar dapat mempersempit batasan-batasan etnis tersebut, perlu dilakukan transformasi identitas etnis melalui model asimilasi dan model akulturasi (Rahmat, 2009).

Hasil penelitian ini menggambarkan bahwa ketiga etnis ini sama-sama memiliki kemampuan untuk melakukan hubungan interaksi sosial antaretnis 
melalui proses asimilasi dan akulturasi, sehingga saling menerima, saling terbuka satu sama lain, dan selalu membangun sikap toleransi antaretnis, dan mampu untuk mengurangi perbedaan antara etnis yang satu dengan etnis lainnya.

Keunggulan model pembelajaran PBMP dalam meningkatkan metakognisi siswa terlihat pada sintaks-sintaks model yakni; pembelajaran berpola PBMP dapat mendorong siswa untuk mengatur proses berpikir mereka melalui pertanyaanpertanyaan yang tersusun secara sistematis dan terarah. Pembelajaran berpola PBMP, tidak ada proses pembelajaran yang berlangsung secara informatif, sehingga tahapan-tahapan pembelajaran PBMP dapat memacu siswa untuk berinteraksi dan bekerja sama secara berkelompok. Hal ini terlihat pada tahap "lakukan". Tahap ini, siswa diberi waktu untuk berkelompok, bekerja sama, dan berdiskusi. Peran aktif siswa dalam tahap ini dapat mengembangkan kesadarannya terkait materi yang dipelajari. Banyaknya waktu berpikir oleh siswa dan saling membantu satu sama lain mengakibatkan siswa lebih banyak terlibat dalam menelaah materi yang tercakup dalam suatu pelajaran (Nurhadi, 2004).

Hasil penelitian ini juga searah dengan pernyataan Arends (2008) yang dikutip oleh Haerullah (2013) bahwa cooperative learning tidak hanya dapat mempengaruhi toleransi dan penerimaan yang lebih luas terhadap siswa-siswa dengan kebutuhan khusus, tetapi juga dapat mendukung terciptanya hubungan yang lebih baik di antara siswa-siswa dengan ras dan etnis yang beranekaragam.

\section{Pengaruh Model Pembelajaran Berpola PBMP dipadu scientific approac terintegrasi nilai Islami terhadap Berpikir Kritis pada Siswa MI Multietnis}

Hasil analisis kovarians menunjukkan bahwa terdapat pengaruh model terhadap keterampilan berpikir kritis siswa SD multietnis. Selanjutnya hasil uji LSD menunjukkan bahwa rata-rata keterampilan berpikir kritis siswa pada model pembelajaran PBMP, berbeda nyata dengan model konvensional. Hasil penelitian ini sejalan dengan hasil penelitian yang telah dijelaskan sebelumnya terkait parameter keterampilan metakognisi. Hasil penelitian ini menunjukkan adanya hubungan antara metakognisi dan keterampilan berpikir kritis. Hubungan dalam arti peningkatan kesadaran metakognisi, sejalan dengan peningkatan keterampilan berpikir kritis.

Meningkat ataupun menurunnya metakognisi, pada akhirnya akan mempengaruhi keterampilan berpikir kritis siswa. Pernyataan tersebut tergambar pada hasil penelitian ini. Siswa yang diberi pembelajaran koopretaif PBMP dipadu scientific approac terintegrasi nilai Islami menunjukkan metakognisi lebih tinggi 
dibanding siswa yang diberi pembelajaran konvensional, demikian pula dengan hasil penelitian terkait berpikir kritis.

Hasil penelitian ini didukung oleh Khan (2008) bahwa pembelajaran konvensional atau pembelajaran yang berpusat pada guru kurang memberikan kesempatan pada siswa untuk mengembangkan keterampilan berpikir kritis. Lebih lanjut dijelaskan oleh Khan (2008) bahwa dominasi guru dalam pembelajaran terlihat dari ceramah atau berbicaranya guru dalam menyampikan informasi atau pengetahuan tanpa memberikan kesempatan kepada siswa untuk berinteraksi. Dengan demikian secara tidak langsung, guru telah membatasi waktu siswa untuk mengembangkan keterampilan berpikir kritisnya. Kondisi proses pembelajaran yang telah diuraikan tersebut sangat bertentangan dengan pandangan (Brown, 2007) bahwa perkembangan keterampilan berpikir kritis dipicu oleh interaksi sosial di antara siswa dalam kelompok belajar. Dengan demikian maka menurut (Brown, 2009) bahwa salah satu cara untuk mengembangkan kemampuan berpikir siswa adalah melalui diskusi bersama teman untuk membicarakan suatu materi pelajaran yang disampaikan oleh guru.

Hasil penelitian ini menunjukkan bahwa model pembelajaran PBMP dipadu scientific approac terintegrasi nilai Islami lebih berpotensi mengembangkan berpikir kritis siswa dibanding model pembelajaran konvensional. Hal ini terlihat dari sintaks strategi pembelajaran PBMP lebih banyak memberikan banyak waktu kepada siswa untuk berinteraksi baik di luar maupun dalam proses pembelajaran. Waktu dan kesempatan yang diperoleh siswa, terlihat dari petunjuk penggunaan LS PBMP, bahwa LS PBMP dapat dibagikan pada siswa 1 minggu sebelum pembeljaran dilaksanakan. Penggunaan waktu seperti ini searah dengan Arends (2008) bahwa kesempatan terpenting dalam pembelajaran kooperatif adalah peluang bagi siswa dengan berbgai kebutuan khusus dan dari beragam latar belakang untuk bekerja bersama dalam kelompok, pembelajaran koopratif juga merupakan salah satu cara yang penting bagi siswa-siswa dengan berbagai disabilitas seperti siswa-siswa yang berasal dari berbagai macam latar belakang rasial dan etnis untuk berpartisipasi penuh dalam kehidupan kelas dalam mengembangkan pemahamannya yang lebih baik.

Berdasarkan hasil analisis kovarian disimpulkan bahwa masing-masing etnis memiliki keterampilan berpikir kritis siswa yang bervariasi. Hasil penelitian ini sejalan dengan penelitian sebelumnya yang dilakukan di Samarinda oleh Maasawet (2009) dengan menerapkan strategi pembelajaran yang strategi pembelajaran kooperatif Snowballing dan Number Head Together (NHT), menyatakan bahwa etnis mempengaruhi keterampilan berpikir kritis siswa. Hasil penelitian ini juga 
diperkuat oleh Kauchak, (2009) bahwa keragaman siswa dapat berpengaruh terhadap hasil belajar karena siswa yang datang ke dalam kelas akan membawa kebutuhan-kebutuhan dan minat-minat yang berbeda-beda.

Menurut Kauchak (2009) menjelaskan bahwa pengaruh keragaman siswa menyebabkan ada perbedaan prestasi. Perbedaan tersebut karena siswa memiliki kecenderungan untuk berhati-hati dengan orang lain yang datang dari latar belakang yang berbeda, akan tetapi sudah merupakan hal yang lumrah dalam rana sosial, dan kecenderungan tersebut juga muncul di sekolah.

Selanjutnya oleh Jacobsen, dkk. (2009) menyatakan bahwa apa yang dibawa siswa ke dalam kelas akan sangat mempengaruhi iklim pembelajaran. Selanjutnya oleh Jerolimek, dkk., (2005) menjelaskan bahwa keragaman pembelajar menyajikan tantangan-tantangan dan kesempatan-kesempatan bagi guru untuk mengatur kelas seefektif mungkin, karena pembelajar memiliki perbedaan dalam berbagai hal seperti karakteristik fisik, minat, kehidupan rumah, kemampuan intelektual, kapasitas belajar, kemampuan motorik, keterampilan sosial, keterampilan dan bakat, keterampilan bahasa, latar belakang, cita-cita, sikap, harapan, dan impian.

Hasil uji anakova juga menunjukkan bahwa interaksi strategi pembelajaran dan etnis tidak berpengaruh terhadap keterampilan berpikir kritis siswa, namun dilakukan uji lanjut dengan menggunakan uji LSD. Hasil uji LSD juga menunjukkan hal yang sama yaitu kelompok kombinasi strategi konvensional dan etnis Ternate, Makian, dan Tidore lebih rendah potensinya dibanding potensi kelompok kombinasi strategi lainnya dalam memberdayakan keterampilan berpikir kritis siswa.

Pembelajaran konvensional atau pembelajaran dengan sistem ceramah, membuat siswa memperoleh pengetahuan yang bersifat hafalan. Menurut Khan (2008) bahwa metode hafalan yang ditekankan pada pembelajaran konvensional, menyebabkan pemahaman siswa pada kemampuan pemahaman materi pelajaran menjadi lemah, dan lemahnya pemahaman siswa terhadap materi tersebut berasosiasi dengan capaian hasil belajar akademiknya (Khan, 2008). Kondisi pembelajaran tersebut juga menjadi salah satu penghambat pencapaian keberhasilan pembelajaran (Zuo, 2011). Selanjutnya Chen (2008) berpendapat bahwa siswa dengan perkembangan afektif yang negative (motivasi belajar rendah dan merasa khawatir dalam lingkungan pembelajaran), akan berdampak pada hasil belajar kognitifnya. Selain itu, telah dijelaskan sebelumnya bahwa pembelajaran konvensional sepenuhnya dikuasai oleh guru sehingga lingkungan kelas tidak memungkinkan siswa untuk mengembangkan kemampuan berpikirnya. Hal ini 
yang mendasari mengapa pembelajaran konvensional menunjukkan potensi terendah dalam upaya memberdayakan keterampilan berpikir kritis siswa dibanding startegi pembelajaran koopretif PBMP.

Terkait potensi strategi pembelajaran PBMP dalam mengembangkan keterampilan berpikir kritis, beberapa hasil penelitian yang dilakukan sebelumnya oleh (Chapsah dan Hasanah, 2004; Sunami dkk, 2002; Mulyati, 2006: Haerullah, $2012^{\text {b }}$ ) melaporkan bahwa pembelajaran PBMP dapat meningkatkan hasil belajar siswa, berpikir kritis siswa serta siswa lebih antusias menjawab pertanyaan, menggunakan kalimat yang lebih runtut dan lengkap, dan siswa juga berani mengungkapkan pendapatnya dengan kalimat yang baik.

Hasil penelitian ini juga sejalan dengan hasil penelitiannya Haerullah $\left(2012^{a}\right)$ bahwa keterampilan berpikir kritis siswa pada kelompok kombinasi model PBMP dengan etnis lebih tinggi dibanding kelompok kombinasi strategi lainnya dengan etnis. Penggunaan pola PBMP lebih meningkatkan keterampilan berpikir kritis siswa disebabkan karena strategi pembelajaran PBMP menekankan proses pembelajaran pada serangkaian pertanyaan-pertanyaan yang disusun secara berurutan, yang tertuang dalam LS PBMP. Kegiatan pembelajaran ini memungkinkan siswa membangun sendiri konsep-konsep yang diperlukan dalam menjawab berbagai rangkaian pertanyaan tersebut, sehingga proses berpikir diberdayakan secara maksimal. Melalui ide-ide yang mereka kemukakan membiasakan siswa untuk berpikir kritis. Menurut (Zaini, 2007) bahwa sesuatu yang selalu diulang-ulang akhirnya akan menjadi suatu kebiasaan. Selanjutnya terkait keunggulan karakteristik pembelajaran berpola PBMP, Amstrong et al., (2005) menjelaskan bahwa dengan menerapkan strategi-strategi questioning secara efektif memungkinkan guru dapat memanfaatkan kekuatan-kekuatan siswa yang beragam etnisnya.

Temuan ini sejalan dengan pendapat Browne \& Keeley (1990) dalam Kauchak (2009) bahwa penggunaan strategi questioning di dalam kelas akan membantu siswa mempelajari konten dan untuk mengajari mereka berpikir lebih kritis dan analitis. Pemikiran kritis merujuk pada karakteristik masing-masing siswa. Lebih lanjut dijelaskan oleh Kauchak (2009) bahwa implementasi strategistrategi questioning yang tepat tentu saja dapat meningkatkan kualitas interaksi verbal, yang merupakan faktor penting dalam memenuhi kebutuhan-kebutuhan siswa yang beragam etnisnya. 


\section{SIMPULAN}

Berdasarkan hasil analisis data dan pembahasan, maka dapat diambil beberapa kesimpulan dari penelitian ini. Kesimpulan tersebut antara lain sebagai berikut:

1. Model pembelajaran berpola PBMP dipadu scientific approac terintegrasi nilai Islami berpengaruh terhadap metakognisi siswa MI Multietnis kota Ternate;

2. Model pembelajaran PBMP dipadu scientific approac terintegrasi nilai Islami berpengaruh terhadapa keterampilan berpikir kritis siswa MI Multietnis Kota Ternate

3. Model Pembelajaran PBMP dipadu scientific approac terintegrasi nilai Islami dan Etnis secara bersama-sama berpengaruh signifikan terhadap keterampilan berpikir kritis dan metakognisi siswa MI Multietnis Kota Ternate.

4. Etnis tidak berpengaruh signifikan terhadap keterampilan berpikir kritis dan metakognisi siswa MI Multietnis Kota Ternate.

5. Siswa pada masing-masing etnis memiliki gaya belajar yang berbeda-beda.

\section{DAFTAR RUJUKAN}

Abdullah, A. 2005. Pendidikan Multikultural. Pilar media. Yogyakarta.

Anderson, 2001. A Taxonomy for Learning, Teaching, and Assessing: A Revision of Bloom's Taxonomy of Educational Objektives. A bridged Edition. David McKay Company, Inc., New York.

Arends. 2008. Learning To Teach. Terjemahan oleh Soecipto. Pustaka Pelajar, Yogyakarta.

Atjo A, 2001. Orang Ternate dan Kebudayaannya. Jakarta: Cekoro.

Brown, A.L. 1987. Metaconition, executive control, self-regulation, and outher More Mysterius Mechanisms. Hillslade, NJ: Lawrence Erlbaum.

Corebima, A.D. 2010. Pemberdayaan Berpikir Melalui Pertanyaan (PBMP) Sebagai Alat Pembelajaran IPA Biologi Konstruktivis Untuk Meningkatkan Penalaran Siswa SLTP Di Jawa Timur. Laporan RUT VIII. Kantor Menteri Negara Riset Dan Teknologi.

Corebima, A.D. 2008. Metakognisi Suatu Ringkasan kajian. Makalah. Jogyakarta: Diklat Guru Mata Pelajaran Biologi.

Corebima, A.D. 2009. Rubrik Keterampilan Metakognisi yang Terintegrasi dengan Tes Essay. Rubrik MAI. Malang.

Darmadi. 2011. Membentuk Peradaban Bangsa Melalui Pendidikan Multi-Etnik. file:///C:/Users/Rizieq/Documents/REFERENSI/Pengajaran\%20Multietnik/ 
membentuk-peradaban-bangsa-melalui.html. On Line. Diakses tanggal 13 Pebruari 2012.

Eggen, P.D , \& Kauchak, D.P. 1996. Strategi for Teacher: Teaching Content and Thinking Skill. USA: Allyn \& Bacon.

Fisher A, 2008. Critical Thinking: An Introduction (Berpikir Kritis: Sebuah Pnegantar) Erlangga. Jakarta.

Gay, G. 2002. The Nature of Metacognition and Its Measuring. Adaptive Technology Ressource Centri. On Line: http://www.Idrc.com/articels.the natur of metakognition.htm. diakses tgl 21 Desember 2010.

Grafura, L. 2007. Pembelajaran Berbasis Multikultural. http://lubisgrafura.com/2007/09/10/pengajaran-berbasis-multikultural diakses pada tanggal 12 Februari 2012.

Habibah, K. N. 2008 . Pengaruh strategi Pembelajaran PBMP (Pemberdayaan Berpikir Melalui Pertanyaan) + TPS ( Think Pair Share) terhadap Kemampuan Berpikir, Keterampilan Metakognitif, dan Pemahaman Konsep Siswa Kelas VII SMPN 4 IV Malang pada Kemampuan Akademik Berbeda. Skripsi tidak diterbitkan. Malang: Universitas Negeri Malang.

Haerullah A. 2012 a . Pengembangan Pertangkat Pembelajaran IPA Berpola Pemberdayaan Berpikir Melalui Pertanyaan (PBMP) dan Think Pair Share (TPS) pada Sekolah Multietnis dan Pengaruh Penerapannya terhadap Kesadaran Matakognisi, Keterampilan Metakognisi, Kemampuan Berpikir Kritis, dan Sikap Sosial Siswa SD Kota Ternate. Disertasi, Universitas Negeri Malang. Tidak dipublikasikan.

Haerullah A, 2012 $2^{\mathrm{b}}$. Potensi pembelajaran berpola pemberdayaan berpikir melalui pertanyaan (PBMP) dipadu think pair share (TPS) dalam upaya memberdayakan metakognisi siswa SD multietnis di Kota Ternate. Jurnal Bionature. Volume 13.Nomor 1 April 2012.

Haerullah A, 2018. Keterampilan Dasar Mengajar Guru IPA. Lintas Nalar. Yogyakarta

Hart, D. 1994. Authentic Assessment A Hand Book for Educators. California. New York: Addison-Wesley Publishing Company.

Ibrahim, G.A. 2007. Dola Bololo: Budaya Berpikir Positif Masyarakat Ternate. Jurnal Ilmiah Tekstual Vol.5. No 7, april 2007. Fakultas Sastra dan Budaya Universitas Khairun Ternate.

Khan, S.A. 2008. An Experimentl Studi To Evaluation Effectivenass of Cooperative Learning Versus Traditional Learning Method. Disertasi Tidak Diterbitkan. International Islamic University.

Kusmarni. 2011. Pendidikan Multikultural. Suatu Kajian Tentang Pendidikan Alternatif Di Indonesia Untuk Merekatkan Kembali Nilai-nilai Persatuan, Kesatuan Dan Berbangsa di Era Global. On Line. http://www.scribd.com/doc/46941375/Pendidikan-Multikultural-DalamPerspektif-Global. 
Lee, S.T. 2009. Examining the Relationship betwin Metacogniyion, Sel-Regulation, an Critical Thinking in Online Socratic Seminasr of High School Social Studies Student. Desertasi Tidak Diterbitkan: The University of Texas at Austin.

Maasawet E.T, 2009. Pengarug Strategi Pembelajaran Koopertif Snowballing dan number head together (NHT) pada sekolah Multietnis terhadap Kemampuan Berpikir Kritis, Hasil Belajar Kognitif Sains Biologi dan Sikap Sosial Siswa SMP Samarinda. Disertasi tidak diterbitkan.

Maududi M.A. 2002. Pengaruh Penerapan Pembelajaran Pola Pemberdayaan Berpikir Melalui Pertanyaan (PBMP) Terhadap Keaktifan dan Hasil Belaiar Siswa. Skripsi. Tidak Diterbitkan. Malang: FMIPA Univesitas Negeri Malang.

Maslikhah, 2007. Quo Vadis, Pendidikan Multikultu, Rekonstruksi Sistem Pendidikan Berbasis Kebangsaan. Surabaya. Stain Salatiga Press

Mulyati, Yayuk. 2006. Penerapan Pemberdayaan Berpikir Melalui Pertanyaan (PBMP) dengan Metode TPS pada Matapelajaran Sains untuk Meningkatkan Aktivitas dan Hasil Belajar siswa Kelas IV MI Jenderal Sudirman Malang. Skripsi tidak diterbitkan. Malang Universitas Negeri Malang.

Parekh.2008. Rethinking Multiculturalism. Keberagaman Budaya dan Teori Politik. Yogyakarta. Kanisius.

Suyanik. 2010. Pengaruh Penerapan Pola Pemberdayaan Berpikir Melalui Pertanyaan (PBMP) Dengan Model TPS dan Strategi ARIAS Terhadap Kemampuan Berpikir Kritis Dan Hasil Belajar Kognitif pada Siswa Kelas X SMA Laboratorium Malang. Tesis yang tidak diterbitkan.

Zubaidah, S. 2001. Implementasi Pembelajaran IPA Biologi dengan PBMP (Pemberdayaan Berpikir Melalui Pertanyaan). Makalah disampaikan pada Pelatihan dan Lokakarya PBMP (Pemberdayaan Berpikir Melalui Pertanyaan) di Universitas Negeri Malang. 31 Agustus-1 September 2001. 